\title{
A Micro Level Analysis of Disparities in Health Care Infrastructure in Birbhum District, West Bengal, India
}

\author{
Sambit Sheet ${ }^{1}$ and Tutul Roy ${ }^{2}$ \\ ${ }^{I}$ Assistant Teacher(Geography), B.M.S Public Institition, Burdwan, W.B.,India \\ ${ }^{2}$ Assistant Teacher(Geography),Usufabad Junior High School, Burdwan, W.B.,India
}

\begin{abstract}
Regional disparities are caused by a number of factors that lead to misallocation, under utilization of resource, etc. Regional disparities lead to various economic, social and cultural problems. In micro-level study, regional disparity is a key factor for development. Especially, for health care infrastructures it becomes a key issue in that region. Health condition of any person shows its economic strength and working ability. It is the way of development.It is the primary need to human beings. In the present paper analyses has been made to study the imbalances in the level of development with spatial emphases on the regional dimension. To analyze the regional disparities of nineteen blocks of Birbhum district, eight variables have been selected.The Deprivation Index and Development Index of every blocks and every variables have done through calculation.In the analysis it has been observed that, the blocks of Sainthia, Bolpur-Santiniketan and Labpur are the more developed blocks in respect to health care infrastructure and the blocks of Nalhati-I, Suri-I, Mayureswar-I and II are the less developed blocks, which needs more planning to develop the health care infrastructure.
\end{abstract}

Keywords: Regional disparities, Deprivation Index, Development Index, Health care infrastructures, Micro-level.

\section{Introduction}

Regional disparities in health care infrastructure are a common problem in both developed and developing countries. But it differs in certain degrees. In India, glaring disparities in the socio-economic and cultural development are found both at inter and intra region (Debapriya and Mahanti, 2000 \& 2006). Though government is trying to reduce the disparities, it needs some proper planning and their implementation. After independence the centralized planning was implemented for eliminating regional inequalities, but it remained a serious problem in India. Regional disparities in India have widened day by day (Joshi, 1997; Krishan, 2001; Singh, 2006).

From pre-historic period, man cannot alive without the three basic needs; Food, Shelter \& Health. Health is not only the physical condition of human beings but also the mental or psychological features of human beings. So, Health is incorporated within the physical as well as mental health. Being a social animal, human needs both these health. Even human behavior is also portrayed through their physical \& mental health. So health is important with respect to social, economical, cultural as well as their physical natures. In modern society, goodness of health or a disease-free health is so important. Every human being wants it, but their economic, environmental and social condition becomes great hindrances in their way. To overcome these diseases and to maintain good health, man had invented medicine. So, the medical facilities are the only way for good health of the people of the third world country like India where social, economic and environmental condition are worse than any other country. Many demographic aspects like, Infant-mortality rate, birth rate, death rate, male-female ratios are also dependent on the medical facilities of an area. If an area is highly facilitated with the medical services, the people of that are better off and vice-versa. So, it indirectly also help the economic condition of that area. The present day medical facilities in the districts of West-Bengal are not so good. Especially the condition of Sadar Hospitals or Municipal Hospitals is to be mentioned. Everyone will be astonished to hear that now a day a municipality has no hospital. This municipality's medical service is guided by a primary health centre. A municipality hospital serves all over the district as it is more developed and more advantageous than any other primary health centre. The people of remote villages depend on that hospital for their treatment. But the painful condition of those hospitals cannot give hope to the rural people. The health care system in West Bengal has a three-tier structure to provide health care services to the people. The primary stage or the first tire is completely developed to serve the rural poor. This primary stage have three types of health institutions: The Sub-Centre (SC), Primary health centre (PHC) and the community health centre (CHC).

In case of medical facility and health infrastructure, Birbhum district is lagging behind to the other districts of West Bengal. There are no State general hospital and medical college in this district. The public health care infrastructure of Birbhum district consists of 58 Primary Health Centres (PHCs) located in various blocks, 15 Block Primary Health Centres (BPHCs) located at the headquarters of the Blocks, 4 Rural Hospitals 
(RH) which are better equipped than the BPHCs and located at block headquarters, 2 Sub-divisional hospitals situated in 2 subdivisions and the district hospital located at the district headquarter. 1243 populations are served per bed in the health centres and hospitals of Birbhum district and at least 100000 populations are served by only 8 doctors which is too little in respect to West Bengal average (46 doctors per 100000 population).

In such scenario it is important to identify the backward regions of this district in respect to health facility and health care infrastructure at block level in terms of development of major components as well as to measure the level of disparities among different blocks.

\section{Objectives:}

The major objectives are as follows:

$>$ To identify the major health care infrastructures of this district.

$>$ To check the disparities of health care in the different blocks of Birbhum district.

$>$ To determine the Deprivation Index of various health care infrastructures.

$>$ To find out the Development Index of different blocks in terms of health care.

\section{Study Area:}

For the present study, Birbhum District of West Bengal (India) has been choosen as a case study. It lies between $23^{\circ} 32^{\prime} 30^{\prime \prime}$ and $24^{0} 35^{\prime} 0^{\prime \prime}$ "north latitude and $88^{\circ} 1^{\prime} 40^{\prime \prime}$ and $8705^{\prime} 25^{\prime \prime}$ east longitude. Birbhum is bounded on the north and west by the state of Jharkhand, on the east by district of Murshidabad and Burdwan and the south by Burdwan. It comprises of nineteen blocks. The district extends over an area of $4545 \mathrm{Sq}$.Kms. having a population of 3015422 (Cencus 2001) with a population density of 663 person per Sq.Kms. According to West Bengal Human Development Report( 2004) it takes $14^{\text {th }}$ position over West Bengal (Fig. 1).

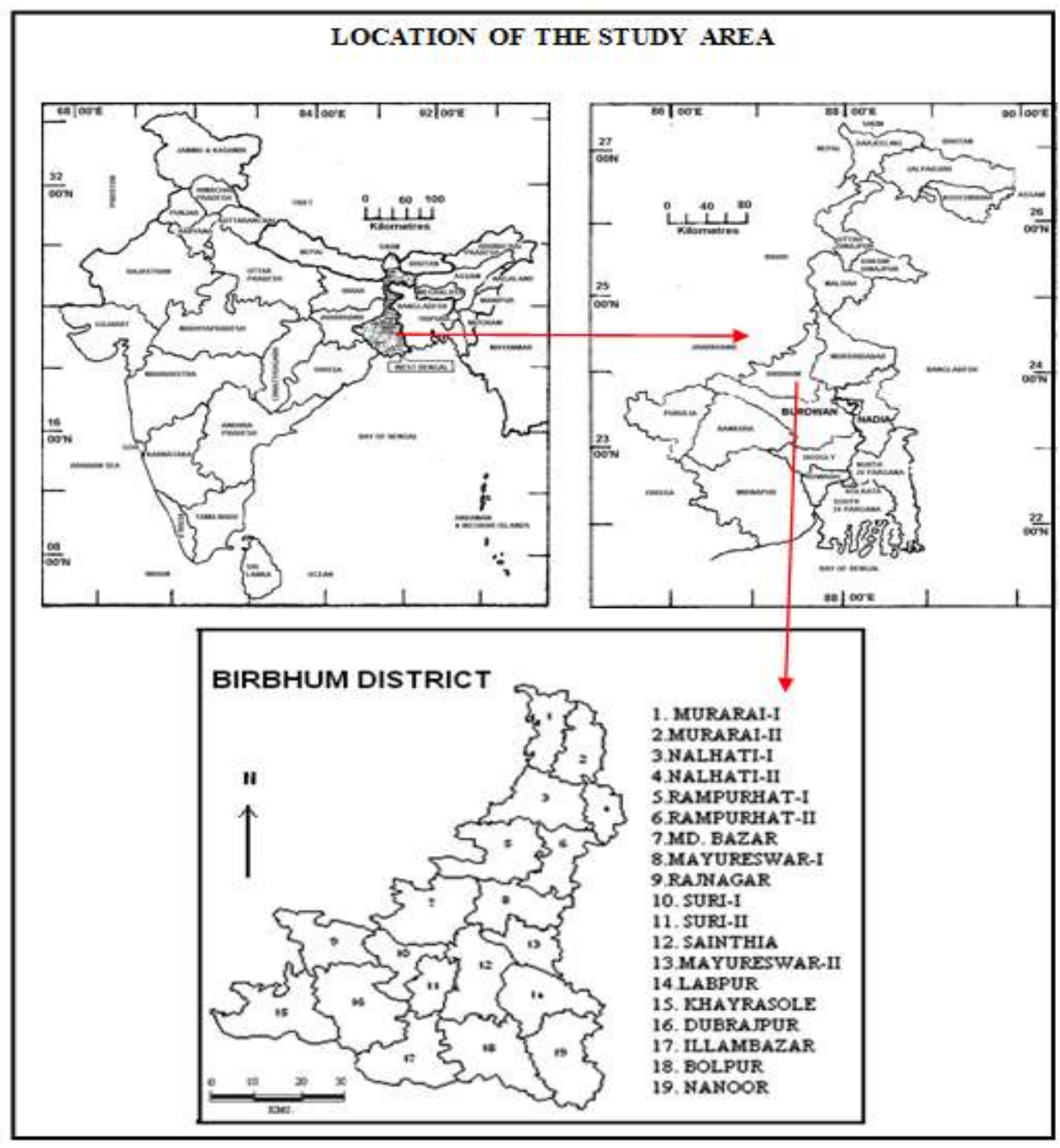




\section{Fig.1: Location map of the Study area}

\section{Methodology:}

In the present analysis block has been taken as the component areal unit of the study area. For the identification of the level of development, we have used 8 indicators. These are:

1) Number of Primary health centre (PHC).

2) Number of medical officers including PHC.

3) Number of other paramedical staff.

4) Number of Staff nurse.

5) Number of hospital beds.

6) Doctors per 10000 populations.

7) Nurse per 10000 population.

8) Beds per 10000 populations.

The datas are exclusively based on secondary sources i.e. District Statistical Hand book of Birbhum, 2006-2007 and Human Development Report of Birbhum District. The information gathered from all such sources was analyzed. And process to give the study a geographical perspective. Keeping all these in mind the present study applies the Deprivation Index and Development Index of health care infrastructure of all individual blocks.

Levels of development at block level, and factors leading to the deprivation have been examined using both deprivation method (Bishnoi and Aneja, 2008). In the deprivation method, the Development Index (DI) is constructed in three steps. The first is to define a measure of deprivation that a region suffers in each selected variable. For computing the index of deprivation is obtained with the following mathematical equation as;

Where,

$$
\text { Iji = Maxi }-\mathbf{X} i j / \text { Maxi }- \text { Mini }
$$

Iji denotes deprivation index of the $\mathrm{i}$ variable at $\mathrm{j}$ unit of study, Maxi and Mini denotes the maximum and minimum values of $i$ th variable in the series respectively, and Xij denotes original value of $i$ variable at $j$ unit of study.

The second step is related to the average deprivation index by taking simple average of all indicators using following equation as;

$$
\mathbf{I j}=\sum \underset{\mathbf{i}=\mathbf{1}}{\mathbf{n}} \mathbf{i j} / \mathbf{n}
$$

Where

Ij denotes the Index of deprivation ( as an average) of jth unit of study.

Finally the Development Index is determined on the basis of the absence of deprivation which is mathematically expressed as

$$
\mathrm{DI}=\left(\mathbf{1}-\sum \mathrm{Iij} / \mathbf{n}\right)
$$

\section{Disparities In Health Care Infrastructures In Birbhum District:}

\section{A) Disparities Through Deprivation:}

With the help of eight health indicators, the deprivation index of each indicators and each block are determined by the above mentioned formula. The block-wise distribution of Deprivation index of different health indicators shows that, in case of primary health centres, Sainthia and Labpur are the only two blocks without deprivation and the blocks of Nalhati-II, Murarai-I, Mayureswar-I, Rajnagar, suri-I, Suri-II and Illambazar are completely deprived as the number of PHC in these blocks are only two each. The blocks of Nalhati-I, Mayureswar-II, Rampurhat-II, Khayrasole, Bolpur-Santiniketon, Nanoor have the considerable number of PHC. In case of number of medical officers including PHC, only Sainthia block is without deprivation. But Suri-I has highest Deprivation Index. Khoyrasole, Mayureswar-I and Nalhati-II are also highly deprived. Number of other paramedical officers are very low in Nalhati-I, Mayureswar-II, Dubrajpur, Khoyrasole and Labpur. Rampurhat-I is the only block which is saturated by other paramedical officers. Sainthia has the highest number of staff nurse while Nalhati-II is completely deprived. Mayureswar-I and Suri-I have the Deprivation Index almost nearer to 1 . In case of number of hospital beds, Sainthia is leading to others but Suri-I, Suri-II, Rajnagar and Nalhati-II are the deprived blocks. Murarai and Labpur, having the Deprivation Index of 0.48 and 0.56 respesctively are almost developing. Sainthia is such a block which is most developed or without any deprivation among the blocks of Birbhum district in respect to other health indicators i.e., number of doctors, number of nurse and number of beds per 10000 populations. The Deprivation Index of this block in 
case of these indicators is 0. But Nalhati-I, Murarai-II, Nanoor and Mayureswar-I are completely deprived in these regard (Table 2).

\section{B) Disparities Through Development:}

With the help of different Deprivation Indexes, the Development Indexes are determined by subtracting the Deprivation Indexes from 1. For each block, the Development Indexes of all indicators are averaged and average Development Indexes are calculated. Highest level of development in health care infrastructure is seen in the block of Sainthia. The average Development Index of this block is 0.96875 . So, Sainthia is the most developed block in Birbhum district in respect to medical facility as well as health care infrastructure. Labpur and Bolpur-Santiniketan ranked second and third respectively, though their Average Development Indexes are much lower than Sainthia. The Average Development Index of these two blocks are 0.5695 and 0.5295 respectively (Fig. 2). Dubrajpur and Murarai-I are the next rank holder with medium Development Index. Mayureswar-I is the most under developed block among the blocks of Birbhum district. The Average Development Index of this block is 0.0644. Nalhati-II, Suri-I and Nalhati-I are also the under developed blocks in respect to health care infrastructure (Table:3). With the help of Average Development Index of 19 blocks of Birbhum district, four distinct zones are evaluated i. e., Developed zone (0.454 to 0.969), medium developed zone (0.349 to 0.454$)$, medium under developed zone (0.2 to 0.349) and under developed zone (0.064 to 0.2$)$. Blocks having high Development Index i. e., Sainthia, Labpur and Bolpur-Santiniketon are the Developed blocks due to the presence of all kinds of health care infrastructural facilities. Nalhati-I, Rampurhat-I, Md. Bazar, Mayureswar-I, Rajnagar and Dubrajpur are the medium developed blocks. The most under developed blocks with least health care infrastructural facility are Khayrasole, Suri-I, Mayureswar-II, Nalhati-I and Nalhati-II. Rests of the blocks of this district are fallen under medium under developed blocks (Table 3).

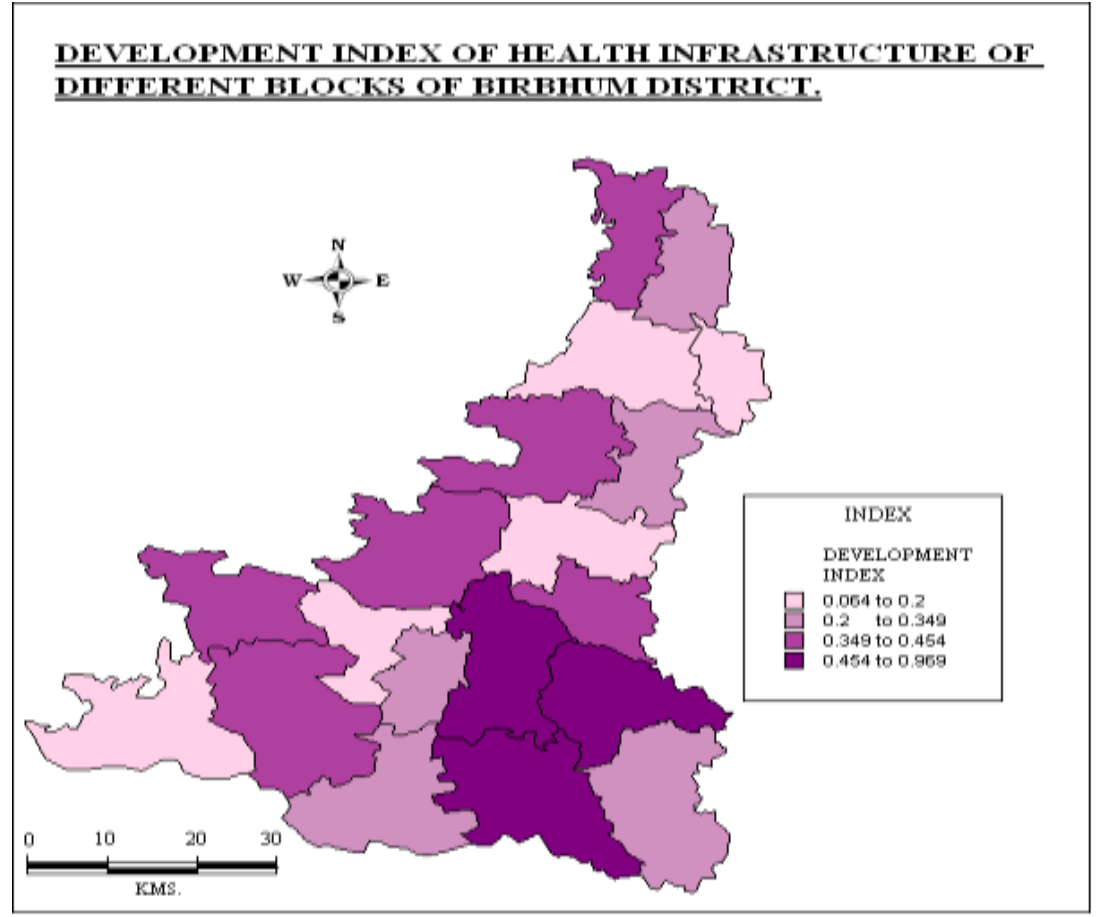

Fig. 2: Development Index of Health Infrastructure of Different Blocks of Birbhum District

\section{Conclusion:}

On the whole, it may be conclude from the present analysis that there is a substantial gap in infrastructure as well as availability of health personnel in the populous blocks of the district and require special attention. In the case of other blocks, it seems that the existing facilities are possibly adequate to meet current healthcare demand. It should also be kept in mind that due to such inadequacies of facilities a large section of the rural population may either seek alternative healthcare from private practitioners (qualified or unqualified), traditional healers or simply do not seek any treatment due to the variety of constraining factors (District Human Development Report, Birbhum, 2006-2007). The blocks of Sainthia, Labpur and Bolpur have adequate medical facilities but the blocks of Rampurhat-I, Nalhati-I, Nalhat-II, Rajnagar, Suri-I, Suri-II, Khoyrasole, MayureswarI and Mayureswar-II are the under developed blocks which require much development in health care and also health care planning. More hospitals, more primary health centers and overall, more doctors and nurse are 
needed immediately to reduce the dependence of private health centers of these blocks. The people of these blocks spend more amounts in health care than food care. In other words, their health cost is more than their food cost. It is necessary to develop their public health conditions i. e., sanitation, toilet facility, sewage facility, and safe drinking water facility etc to develop the health care infrastructures of these blocks.

\section{Acknowledgements:}

Authors are grateful to Dr. S. C. Mukhopadhyay, Professor (Retd.),Department of Geography, Calcutta University, India. for his constant guidance and valuable suggestions. They are also beholden to Mr. Milan Mandal, research scholar ,Department of Geography. Burdwan University for his kind co-operation and valuable suggestions.

\section{References:}

[1] Debapriya, A. and Mohanty, M.K. (2006). Inter District Variation in the level of Industrial Development of Orissa: A Quantitative Analysis, Asian Economic Review, Vol. 48, No.1.

[2] Debapriya, A. and Mohanty, M.K. (2000). Inter District Variation in the Level of Human development in Orissa, Utkal Economic paper, vol-12, pp.50-53

[3] Jishi, Samir (1997). Regional Disparities in Industrial Development, Indian Journal of Regional Science, Vol. 29, No.1.

[4] Krishan, G. (2000). Development, Environment and Decentralized Planning, Presidential Address, 22 Indian Geography Congress (NAGI), Dhawad (Karnataka), India.

[5] Krishan, G. (2001). Presidential address:. Development, Environment and Decentralized planning, Annals of NAGI, Vol. 21, No.1, Jan- 2001 pp.2-22.

[6] Singh R. (2006). Regional Disparities in level of socio-economic Development in post Reforms Period: A District level Analysis, Annals of NAGI, Vol. 26, Dec., No.2, pp.87-94.

[7] District Statistical Handbook of Birbhum, 2007-2008

[8] Human Development Report of Birbhum District 2007

Table 1: Health Care Infrastructures of different blocks of Birbhum District

\begin{tabular}{|c|c|c|c|c|c|c|c|c|c|}
\hline BLOCKS & $\begin{array}{c}\text { PROJEC } \\
\text { TED } \\
\text { POPULA } \\
\text { TION, } \\
2007\end{array}$ & 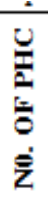 & $\begin{array}{c}\text { NO. OF } \\
\text { MEDICAL } \\
\text { OFFICERS } \\
\text { INCLUDIN } \\
\text { G PHC }\end{array}$ & $\begin{array}{l}\text { NO. OF } \\
\text { OTHER } \\
\text { PARAME } \\
\text { DICAL } \\
\text { STAFF }\end{array}$ & $\begin{array}{l}\text { STAFF } \\
\text { NURSE }\end{array}$ & $\begin{array}{c}\text { NO. OF } \\
\text { HOSPITA } \\
\text { L BEDS }\end{array}$ & $\begin{array}{c}\text { DOCTORS/I } \\
0000 \\
\text { POPULATIO } \\
\mathrm{N}\end{array}$ & $\begin{array}{l}\text { NURSE/10000 } \\
\text { POPULATION }\end{array}$ & $\begin{array}{c}\text { BEDS/10000 } \\
\text { POPULATIO } \\
\mathrm{N}\end{array}$ \\
\hline NALHATI-I & 250616 & 3 & 6 & 4 & 16 & 47 & 2 & 6 & 2 \\
\hline NALHATI-II & 120002 & 2 & 3 & 5 & 7 & 31 & 2 & 6 & 3 \\
\hline MURARAI-I & 177255 & 2 & 6 & 7 & 18 & 66 & 3 & 10 & 4 \\
\hline MURARAI-II & 200924 & 4 & 5 & 6 & 13 & 47 & 2 & 6 & 2 \\
\hline $\begin{array}{l}\text { MAYURESWAR- } \\
\text { I }\end{array}$ & 155768 & 2 & 3 & 5 & 9 & 31 & $\frac{2}{2}$ & 6 & $\frac{2}{2}$ \\
\hline $\begin{array}{l}\text { MAYURESWAR- } \\
\text { II }\end{array}$ & 122522 & 3 & 6 & 4 & 11 & 52 & 5 & 9 & 4 \\
\hline RAMPURHAT-I & 176269 & 4 & 6 & 8 & 13 & 43 & 3 & 7 & 2 \\
\hline RAMPURHAT-II & 172292 & 3 & 6 & 6 & 11 & 52 & 3 & 6 & 3 \\
\hline MD. BAZAR & 155508 & 4 & 5 & 5 & 14 & 62 & 3 & 9 & 4 \\
\hline SAINTHIA & 174963 & 5 & 10 & 7 & 30 & 102 & 6 & 17 & 6 \\
\hline DUBRAJPUR & 175901 & 4 & 8 & 4 & 17 & 58 & 5 & 10 & 3 \\
\hline RANNAGAR & 75094 & 2 & 4 & 5 & 11 & 31 & 5 & 15 & 4 \\
\hline SURI-I & 110084 & 2 & 2 & 6 & 9 & 27 & 2 & 8 & 2 \\
\hline SURI-II & 85120 & 2 & 4 & 5 & 11 & 31 & 5 & 13 & 4 \\
\hline KHOYRASOLE & 143570 & 3 & 3 & 4 & 14 & 37 & 2 & 10 & 3 \\
\hline $\begin{array}{c}\text { BOLPUR- } \\
\text { SANTINIKETAN }\end{array}$ & 195847 & 3 & 5 & 7 & 23 & 86 & 3 & 12 & 4 \\
\hline LABHPUR & 192524 & 5 & 9 & 4 & 23 & 60 & 5 & 12 & 3 \\
\hline NANOOR & 210827 & 3 & 5 & 6 & 13 & 37 & 2 & 6 & 2 \\
\hline ILLAMBAZAR & 162037 & 2 & 7 & 5 & 13 & 46 & 4 & 8 & 3 \\
\hline
\end{tabular}

Source: Human Development Report, Birbhum, 2007 
Table 2: Deprivation Index of Health Care Facilities

\begin{tabular}{|c|c|c|c|c|c|c|c|c|}
\hline BLOCKS & 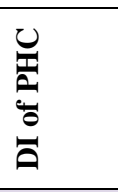 & $\begin{array}{l}\text { DI of } \\
\text { medical } \\
\text { officers } \\
\text { includi } \\
\text { ng PHC }\end{array}$ & $\begin{array}{l}\text { DI of no } \\
\text { of other } \\
\text { paramedi } \\
\text { cal staffs }\end{array}$ & $\begin{array}{l}\text { DI of staff } \\
\text { nurse }\end{array}$ & $\begin{array}{l}\text { DI of no } \\
\text { of } \\
\text { hospital } \\
\text { beds }\end{array}$ & $\begin{array}{l}\text { DI of } \\
\text { doctors/100 } \\
\text { 00 } \\
\text { population }\end{array}$ & $\begin{array}{l}\text { DI of } \\
\text { nurse/100 } \\
00 \\
\text { populatio } \\
\text { n }\end{array}$ & $\begin{array}{l}\text { DI of } \\
\text { beds/1000 } \\
\text { 0 } \\
\text { populatio } \\
\text { n }\end{array}$ \\
\hline NALHATI-I & 0.6667 & 0.5 & 1 & 0.608696 & $\begin{array}{r}0.73333 \\
3\end{array}$ & 1 & 1 & 1 \\
\hline NALHATI-II & 1 & 0.875 & 0.75 & 1 & $\begin{array}{r}0.94666 \\
7\end{array}$ & 1 & 1 & 0.75 \\
\hline MURARAI-I & 1 & 0.5 & 0.25 & 0.521739 & 0.48 & 0.75 & 0.636364 & 0.5 \\
\hline $\begin{array}{c}\text { MURARAI- } \\
\text { II }\end{array}$ & 0.3333 & 0.625 & 0.5 & 0.73913 & $\begin{array}{r}0.73333 \\
3\end{array}$ & 1 & 1 & 1 \\
\hline $\begin{array}{c}\text { MAYURES } \\
\text { WAR-I }\end{array}$ & 1 & 0.875 & 0.75 & 0.913043 & $\begin{array}{r}0.94666 \\
7\end{array}$ & 1 & 1 & 1 \\
\hline $\begin{array}{c}\text { MAYURES } \\
\text { WAR-II }\end{array}$ & 0.6667 & 0.5 & 1 & 0.826087 & $\begin{array}{r}0.66666 \\
7\end{array}$ & 0.25 & 0.727273 & 0.5 \\
\hline $\begin{array}{c}\text { RAMPURH } \\
\text { AT-I }\end{array}$ & 0.3333 & 0.5 & 0 & 0.73913 & $\begin{array}{r}0.78666 \\
7\end{array}$ & 0.75 & 0.909091 & 1 \\
\hline $\begin{array}{c}\text { RAMPURH } \\
\text { AT-II }\end{array}$ & 0.6667 & 0.5 & 0.5 & 0.826087 & $\begin{array}{r}0.66666 \\
7\end{array}$ & 0.75 & 1 & 0.75 \\
\hline MD. BAZAR & 0.3333 & 0.625 & 0.75 & 0.695652 & $\begin{array}{r}0.53333 \\
3\end{array}$ & 0.75 & 0.727273 & 0.5 \\
\hline SAINTHIA & 0 & 0 & 0.25 & 0 & 0 & 0 & 0 & 0 \\
\hline $\begin{array}{c}\text { DUBRAJPU } \\
\mathbf{R}\end{array}$ & 0.3333 & 0.25 & 1 & 0.565217 & $\begin{array}{r}0.58666 \\
7 \\
\end{array}$ & 0.25 & 0.636364 & 0.75 \\
\hline RAJNAGAR & 1 & 0.75 & 0.75 & 0.826087 & $\begin{array}{r}0.94666 \\
7 \\
\end{array}$ & 0.25 & 0.181818 & 0.5 \\
\hline SURI-I & 1 & 1 & 0.5 & 0.913043 & 1 & 1 & .818182 & 1 \\
\hline SURI-II & 1 & 0.75 & 0.75 & 0.826087 & $\begin{array}{r}0.94666 \\
7\end{array}$ & 0.25 & 0.363636 & 0.5 \\
\hline $\begin{array}{c}\text { KHOYRASO } \\
\text { LE }\end{array}$ & 0.6667 & 0.875 & 1 & 0.695652 & $\begin{array}{r}0.86666 \\
7\end{array}$ & 1 & 0.636364 & 0.75 \\
\hline $\begin{array}{l}\text { BOLPUR- } \\
\text { SANTINIKE } \\
\text { TAN }\end{array}$ & 0.6667 & 0.625 & 0.25 & 0.304348 & $\begin{array}{r}0.21333 \\
3\end{array}$ & 0.75 & 0.454545 & 0.5 \\
\hline LABHPUR & 0 & 0.125 & 1 & 0.304348 & 0.56 & 0.25 & 0.454545 & 0.75 \\
\hline NANOOR & 0.6667 & 0.625 & 0.5 & 0.73913 & $\begin{array}{r}0.86666 \\
7\end{array}$ & 1 & 1 & 1 \\
\hline $\begin{array}{c}\text { ILLAMBAZ } \\
\text { AR }\end{array}$ & 1 & 0.375 & 0.75 & 0.73913 & $\begin{array}{r}0.74666 \\
7\end{array}$ & 0.5 & 0.818182 & 0.75 \\
\hline
\end{tabular}

Source: Calculated by Authors

Table 3: Block Wise Rank of Average Development Index

\begin{tabular}{|c|c|c|c|c|c|c|c|c|c|c|}
\hline BLOCKS & $\begin{array}{l}\text { DI of } \\
\text { PHC }\end{array}$ & $\begin{array}{l}\text { DI of } \\
\text { medi } \\
\text { cal } \\
\text { office } \\
\text { rs } \\
\text { inclu } \\
\text { ding } \\
\text { PHC }\end{array}$ & $\begin{array}{l}\text { DI of } \\
\text { no of } \\
\text { other } \\
\text { parame } \\
\text { dical } \\
\text { staffs }\end{array}$ & $\begin{array}{l}\text { DI of } \\
\text { staff } \\
\text { nurse }\end{array}$ & $\begin{array}{l}\text { DI of } \\
\text { no of } \\
\text { hospital } \\
\text { beds }\end{array}$ & 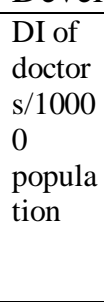 & $\begin{array}{l}\text { DI of } \\
\text { nurse/1 } \\
0000 \\
\text { pop[ula } \\
\text { trion }\end{array}$ & $\begin{array}{l}\mathrm{DI} \text { of } \\
\text { beds } / 1 \\
0000 \\
\text { popula } \\
\text { tion }\end{array}$ & $\begin{array}{l}\text { AVERA } \\
\text { GE } \\
\text { DEVEL } \\
\text { OPMEN } \\
\text { T } \\
\text { INDEX }\end{array}$ & \begin{tabular}{|l}
$\mathrm{BL}$ \\
$\mathrm{OC}$ \\
$\mathrm{K}$ \\
$\mathrm{WI}$ \\
$\mathrm{SE}$ \\
$\mathrm{RA}$ \\
$\mathrm{NK}$
\end{tabular} \\
\hline $\begin{array}{c}\text { NALHATI } \\
\text {-I }\end{array}$ & $\begin{array}{c}0.333333 \\
333\end{array}$ & 0.5 & 0 & $\begin{array}{r}0.39130 \\
4348\end{array}$ & $\begin{array}{r}0.26666 \\
6667\end{array}$ & $\overline{0}$ & 0 & 0 & $\begin{array}{r}0.18641 \\
3043 \\
\end{array}$ & 16 \\
\hline $\begin{array}{c}\text { NALHATI } \\
\text {-II }\end{array}$ & 0 & 0.125 & 0.25 & 0 & $\begin{array}{r}0.05333 \\
3333\end{array}$ & 0 & 0 & 0.25 & $\begin{array}{r}0.08479 \\
1667\end{array}$ & 18 \\
\hline $\begin{array}{c}\text { MURARAI } \\
\text {-I }\end{array}$ & 0 & 0.5 & 0.75 & $\begin{array}{r}0.47826 \\
087 \\
\end{array}$ & 0.52 & 0.25 & $\begin{array}{r}0.3636 \\
36364 \\
\end{array}$ & 0.5 & $\begin{array}{r}0.42023 \\
7154 \\
\end{array}$ & 5 \\
\hline $\begin{array}{c}\text { MURARAI } \\
\text {-II }\end{array}$ & $\begin{array}{c}0.666666 \\
667\end{array}$ & 0.375 & 0.5 & $\begin{array}{r}0.26086 \\
9565\end{array}$ & $\begin{array}{r}0.26666 \\
6667\end{array}$ & 0 & 0 & 0 & $\begin{array}{r}0.25865 \\
0362\end{array}$ & 13 \\
\hline $\begin{array}{c}\text { MAYURE } \\
\text { SWAR-I }\end{array}$ & 0 & 0.125 & 0.25 & $\begin{array}{r}0.08695 \\
6522 \\
\end{array}$ & $\begin{array}{r}0.05333 \\
3333 \\
\end{array}$ & 0 & 0 & 0 & $\begin{array}{r}0.06441 \\
1232 \\
\end{array}$ & 19 \\
\hline
\end{tabular}


A Micro Level Analysis Of Disparities In Health Care Infrastructure In Birbhum District, West

\begin{tabular}{|c|c|c|c|c|c|c|c|c|c|c|}
\hline $\begin{array}{l}\text { MAYURE } \\
\text { SWAR-II }\end{array}$ & $\begin{array}{c}0.333333 \\
333\end{array}$ & 0.5 & 0 & $\begin{array}{r}0.17391 \\
3043\end{array}$ & $\begin{array}{r}0.33333 \\
3333\end{array}$ & 0.75 & $\begin{array}{r}0.2727 \\
27273\end{array}$ & 0.5 & $\begin{array}{r}0.35791 \\
3373\end{array}$ & 8 \\
\hline $\begin{array}{c}\text { RAMPUR } \\
\text { HAT-I }\end{array}$ & $\begin{array}{c}0.666666 \\
667\end{array}$ & 0.5 & 1 & $\begin{array}{r}0.26086 \\
9565\end{array}$ & $\begin{array}{r}0.21333 \\
3333\end{array}$ & 0.25 & $\begin{array}{r}0.0909 \\
09091\end{array}$ & 0 & $\begin{array}{r}0.37272 \\
2332\end{array}$ & 7 \\
\hline $\begin{array}{c}\text { RAMPUR } \\
\text { HAT-II }\end{array}$ & $\begin{array}{c}0.333333 \\
333\end{array}$ & 0.5 & 0.5 & $\begin{array}{r}0.17391 \\
3043\end{array}$ & $\begin{array}{r}0.33333 \\
3333\end{array}$ & 0.25 & 0 & 0.25 & $\begin{array}{r}0.29257 \\
2464\end{array}$ & 11 \\
\hline $\begin{array}{c}\text { MD. } \\
\text { BAZAR }\end{array}$ & $\begin{array}{c}0.666666 \\
667 \\
\end{array}$ & 0.375 & 0.25 & $\begin{array}{r}0.30434 \\
7826 \\
\end{array}$ & $\begin{array}{r}0.46666 \\
6667 \\
\end{array}$ & 0.25 & $\begin{array}{r}0.2727 \\
27273 \\
\end{array}$ & 0.5 & $\begin{array}{r}0.38567 \\
6054 \\
\end{array}$ & 6 \\
\hline SAINTHIA & 1 & 1 & 0.75 & 1 & 1 & 1 & 1 & 1 & 0.96875 & 1 \\
\hline $\begin{array}{c}\text { DUBRAJP } \\
\text { UR }\end{array}$ & $\begin{array}{c}0.666666 \\
667\end{array}$ & 0.75 & 0 & $\begin{array}{r}0.43478 \\
2609 \\
\end{array}$ & $\begin{array}{r}0.41333 \\
3333 \\
\end{array}$ & 0.75 & $\begin{array}{r}0.3636 \\
36364 \\
\end{array}$ & 0.25 & $\begin{array}{r}0.45355 \\
2372 \\
\end{array}$ & 4 \\
\hline $\begin{array}{c}\text { RAJNAGA } \\
\text { R } \\
\end{array}$ & 0 & 0.25 & 0.25 & $\begin{array}{r}0.17391 \\
3043 \\
\end{array}$ & $\begin{array}{r}0.05333 \\
3333 \\
\end{array}$ & 0.75 & $\begin{array}{r}0.8181 \\
81818 \\
\end{array}$ & 0.5 & $\begin{array}{r}0.34942 \\
8524 \\
\end{array}$ & 9 \\
\hline SURI-I & 0 & 0 & 0.5 & $\begin{array}{r}0.08695 \\
6522 \\
\end{array}$ & 0 & 0 & $\begin{array}{r}0.1818 \\
18182 \\
\end{array}$ & 0 & $\begin{array}{r}0.09609 \\
6838 \\
\end{array}$ & 17 \\
\hline SURI-II & 0 & 0.25 & 0.25 & $\begin{array}{r}0.17391 \\
3043 \\
\end{array}$ & $\begin{array}{r}0.05333 \\
3333 \\
\end{array}$ & 0.75 & $\begin{array}{r}0.6363 \\
63636 \\
\end{array}$ & 0.5 & $\begin{array}{r}0.32670 \\
1252 \\
\end{array}$ & 10 \\
\hline $\begin{array}{c}\text { KHOYRA } \\
\text { SOLE }\end{array}$ & $\begin{array}{c}0.333333 \\
333 \\
\end{array}$ & 0.125 & 0 & $\begin{array}{r}0.30434 \\
7826 \\
\end{array}$ & $\begin{array}{r}0.13333 \\
3333 \\
\end{array}$ & 0 & $\begin{array}{r}0.3636 \\
36364 \\
\end{array}$ & 0.25 & $\begin{array}{r}0.18870 \\
6357 \\
\end{array}$ & 15 \\
\hline $\begin{array}{l}\text { BOLPUR- } \\
\text { SANTINIK } \\
\text { ETAN }\end{array}$ & $\begin{array}{c}0.333333 \\
333\end{array}$ & 0.375 & 0.75 & $\begin{array}{r}0.69565 \\
2174\end{array}$ & $\begin{array}{r}0.78666 \\
6667\end{array}$ & 0.25 & $\begin{array}{r}0.5454 \\
54545\end{array}$ & 0.5 & $\begin{array}{r}0.52951 \\
334\end{array}$ & 3 \\
\hline LABHPUR & 1 & 0.875 & 0 & $\begin{array}{r}0.69565 \\
2174 \\
\end{array}$ & 0.44 & 0.75 & $\begin{array}{r}0.5454 \\
54545 \\
\end{array}$ & 0.25 & $\begin{array}{r}0.56951 \\
334 \\
\end{array}$ & 2 \\
\hline NANOOR & $\begin{array}{c}0.333333 \\
333 \\
\end{array}$ & 0.375 & 0.5 & $\begin{array}{r}0.26086 \\
9565 \\
\end{array}$ & $\begin{array}{r}0.13333 \\
3333 \\
\end{array}$ & 0 & 0 & 0 & $\begin{array}{r}0.20031 \\
7029 \\
\end{array}$ & 14 \\
\hline $\begin{array}{c}\text { ILLAMBA } \\
\text { ZAR }\end{array}$ & 0 & 0.625 & 0.25 & $\begin{array}{r}0.26086 \\
9565\end{array}$ & $\begin{array}{r}0.25333 \\
3333\end{array}$ & 0.5 & $\begin{array}{r}0.1818 \\
18182\end{array}$ & 0.25 & $\begin{array}{r}0.29012 \\
7635\end{array}$ & 12 \\
\hline
\end{tabular}

Source: Calculated by Authors 